\title{
(2) OPEN ACCESS \\ Necrotising granulomatous mass of the foreskin with inguinal lymphadenopathy: a rare presentation of syphilis
}

\author{
Cecile Pham, ${ }^{1}$ Luke Wang, ${ }^{1}$ Vivienne Lea, ${ }^{2}$ Prem Rathore ${ }^{1}$
}

\begin{abstract}
'Urology, Campbelltown Hospital, Campbelltown, New South Wales, Australia ${ }^{2}$ Anatomical Pathology, Liverpool Hospital, Liverpool, New South Wales, Australia
\end{abstract}

Correspondence to Dr Cecile Pham; cecile.t.pham@gmail.com

Accepted 27 February 2021

\section{Check for updates}

(c) BMJ Publishing Group Limited 2021. Re-use permitted under CC BY-NC. No commercial re-use. See rights and permissions. Published by BMJ.

To cite: Pham C, Wang L, Lea V, et al. BMJ Case

Rep 2021;14:e238539.

doi:10.1136/bcr-2020-

238539

\section{SUMMARY}

We report the case of a 24-year-old man who presented with a 5-week history of painful right inguinal lymphadenopathy, weight loss and non-ulcerative foreskin mass. The patient's symptoms progressed despite initial antibiotic therapy. The foreskin mass was clinically suspicious for squamous cell carcinoma; however, histopathology of both the foreskin mass and inguinal lymph node showed necrotising granulomatous inflammation. Extensive immunohistochemistry testing was inconclusive and could not identify a causative microorganism. Ultimately, serology was positive for Treponema pallidum and he was treated with intramuscular benzathine penicillin. This is an unusual case, which highlights the importance of extensive investigation for differential diagnoses of penile mass and exemplifies the resurgence of syphilis in developed countries.

\section{INTRODUCTION}

Penile lesions can arise from the epithelium of the foreskin, glans or shaft. They are a diagnostic challenge largely guided by clinical presentation and physical examination. The broad differential for penile lesions includes sexually acquired and non-sexually acquired infections, malignant and premalignant lesions, inflammatory conditions, trauma and, rarely, iatrogenic causes (such as reactive inflammation due to foreign body material). ${ }^{1-5}$ Infectious aetiology includes viral, parasitic and bacterial infections, with the most prevalent being human papilloma virus (HPV), herpes simplex virus (HSV), scabies and syphilis. Infectious penile lesions have vastly different appearances: HPVinduced condyloma appears as soft, papillomatous growths; HSV presents as genital ulceration; scabies causes papules with multiple linear burrows; and syphilis typically presents as a solitary, painless ulcer with well-defined margins and indurated base. ${ }^{6}$ Penile carcinoma is rare but should be considered in men with suspicious mass or ulcer of the penis. ${ }^{7}$ Squamous cell carcinoma (SCC) accounts for the majority of penile cancers. Other penile cancers include melanoma, Kaposi's sarcoma, basal cell carcinoma and lymphoma. Carcinoma in situ often presents as solitary, painless lesions, similar to invasive SCC. Definitive diagnosis of penile carcinoma requires tissue biopsy for histopathological confirmation. Although most penile SCCs arise de novo, some are preceded by premalignant lesions, such as cutaneous horn and lichen sclerosus. ${ }^{89}$ Cutaneous horn presents as overgrowth and cornification of epithelium, creating a solid protuberance, whereas lichen sclerosus appears as a phimotic, hypopigmented foreskin or glans. ${ }^{6}$

\section{CASE PRESENTATION}

A 24-year-old urban indigenous Australian heterosexual man was admitted with a 5 -week history of painful right inguinal lymphadenopathy and foreskin mass. He reported penile pain, which he initially attributed to sustaining a physical blow to his groin, but did not notice a mass at the time. He noted some dysuria but denied any haematuria or penile discharge. He reported a 2-week history of constitutional symptoms, including low-grade fevers, chills and rigours, night sweats, anorexia and unintentional weight loss of $\sim 5 \mathrm{~kg}$.

In the 2 weeks leading up to admission, he presented multiple times to both a general practitioner and emergency department. He underwent an inguinal ultrasound that showed an enlarged inguinal lymph node measuring $2.0 \times 2.3 \times 3.4$ $\mathrm{cm}$ with increased vascularity. The findings were suggestive of lymphadenitis. He completed two courses of amoxicillin/clavulanic acid, but his symptoms progressed. He eventually represented with worsening inguinal lymphadenopathy and new penile pain.

He reported life-long phimosis. He is otherwise healthy with no other significant medical or family history. He reported being sexually active with one regular female partner, and no additional risk factors for sexually transmitted infections (STIs) were identified.

His observations were unremarkable and he was afebrile on presentation. On examination, there was a hard, nodular mass on the ventral aspect of his distal foreskin. He had a tight, non-retractable phimosis and the foreskin was mildly erythematous. He had bilateral inguinal lymphadenopathy, right more prominent than left. The lymph nodes were hard, fixed and exquisitely tender.

\section{INVESTIGATIONS}

White cell count was mildly elevated at $11.8 \times 10^{9} / \mathrm{L}$, and $\mathrm{C}$ reactive protein was $124 \mathrm{mg} / \mathrm{L}$. Urine and blood cultures were negative. Genital swab and urine PCR were negative for Chlamydia trachomatis and Neisseria gonorrhoeae. Repeat ultrasound of the right groin showed an enlarged lymph node measuring $2.8 \times 2.9 \times 3.2 \mathrm{~cm}$, demonstrating increased vascularity and a thickened cortex with 


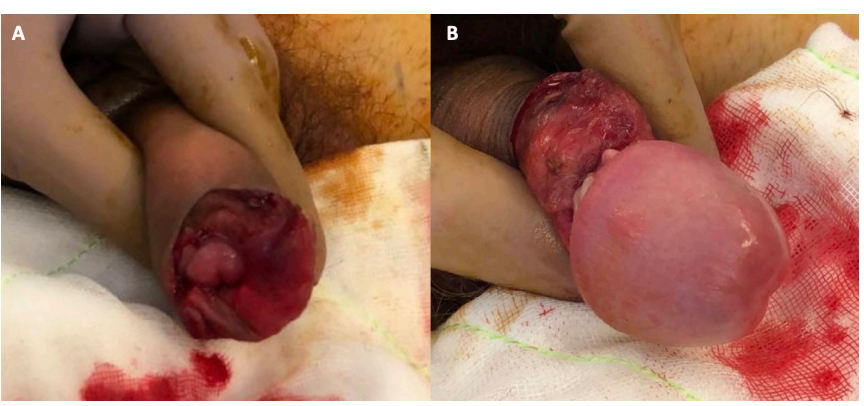

Figure 1 Intraoperative images of the penis and foreskin during circumcision (A) showing no macroscopic involvement of the corpora or glans penis (B).

surrounding subcutaneous oedema. There was no drainable collection.

\section{TREATMENT}

He was treated empirically with intravenous flucloxacillin and gentamicin. Given antibiotics were unsuccessful and the patient had significant constitutional symptoms, the lesion was considered suspicious for penile carcinoma. He subsequently underwent circumcision and excisional biopsy of the right inguinal lymph node. During surgery, sleeve technique circumcision was performed to excise the mass from the distal foreskin. There was no macroscopic involvement of the corpora or glans penis (figure 1). The inguinal node was noted to be necrotic and discharged pus. The foreskin and right inguinal lymph node were sent for histopathology.

Histological examination of the $25 \times 20 \mathrm{~mm}$ ulcerated foreskin lesion showed florid granulomatous inflammation with foci of necrosis (figure 2). The inflammatory infiltrate also included some plasma cells and lymphocytes. Similarly, the lymph node showed necrotising granulomatous inflammation. There was no evidence of malignancy. The findings of necrotising granulomatous inflammation were highly suggestive of an infectious aetiology. The differential diagnosis for this histological appearance at this site included lymphogranuloma venereum and granuloma inguinale. Other considerations were syphilis, mycobacterial, atypical mycobacterial or fungal infections. Subsequently, a range of stains were performed in an attempt to detect a causative organism. A Warthin-Starry stain showed a few possible organisms, however was difficult to interpret due to background staining. No organisms were seen on other stains, including a modified Ziehl-Neelsen, auramine, Periodic Acid-Schiff for fungus, Grocott's methenamine silver, gram stain or a Treponema pallidum immunoperoxidase stain.

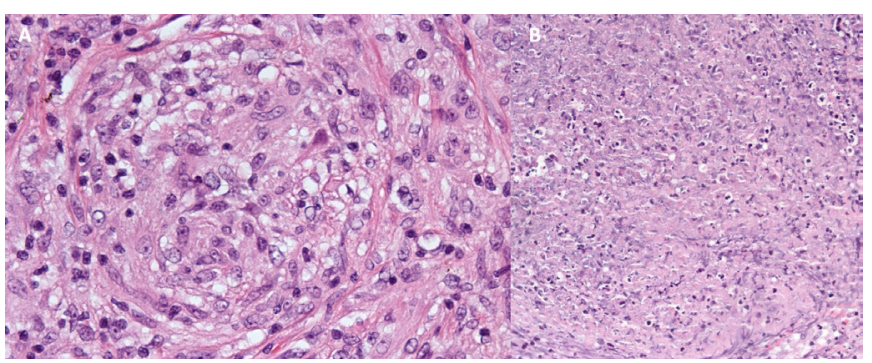

Figure 2 The foreskin lesion consisted of granulomatous inflammation (A) with associated necrosis (B). Both slides are H\&E stain, $\times 40$ magnification.

\section{OUTCOME AND FOLLOW-UP}

He was subsequently referred to the sexual health clinic. Serological screening showed positive treponemal-specific antibody tests and a rapid plasma regain titre of $1: 8$, consistent with infectious syphilis. Serology was negative for hepatitis B, HIV and HSV type 2. Screening for C. trachomatis and N. gonorrhoeae by urine PCR testing was negative. Subsequently, the lymph node was reviewed and found to be syphilis PCR-positive. A revised sexual history revealed an additional female sexual partner approximately 6 months prior to symptom onset. The patient was treated with benzathine penicillin. The lymphadenopathy resolved and he was clinically well at 1-month follow-up review.

\section{DISCUSSION}

This case demonstrates a rare presentation of penile mass. We highlight the importance of considering broad differential diagnoses as not all isolated penile masses are malignant. A multidisciplinary approach to assessment and management is essential given the multitude of differentials. There has been a resurgence of syphilis within developed countries, and screening for STIs is paramount prior to diagnostic biopsy and radical excision.

The inconclusive finding of necrotising granulomatous inflammation from the foreskin and inguinal lymph node histopathology posed a diagnostic dilemma and required further clinical investigation. Granulomatous inflammation is a pattern of chronic inflammation due to various infectious, autoimmune, toxic, allergic and neoplastic causes. ${ }^{10}$ Identifying specific patterns of granulomatous inflammation, such as necrotising granulomas in this case, favours an infectious aetiology. The differential diagnosis for this histological appearance in the foreskin includes lymphogranuloma venereum and granuloma inguinale. However, necrotising granulomas are more commonly caused by tuberculous and non-tuberculous mycobacteria or fungal species. ${ }^{11}$ Syphilis may have a variety of histological patterns of inflammation, and although rare, granulomatous inflammation has been shown within nodular cutaneous lesions of secondary syphilis. ${ }^{5} 12$

Syphilis is an STI caused by the spirochete bacterium T. pallidum. The typical histological method of detecting spirochetes is silver impregnation, such as Warthin-Starry staining. ${ }^{5}$ However, they are often difficult to identify due to marked background staining, which was the case in our tissue sections. Studies have shown that immunohistochemistry with a monoclonal antibody for T. pallidum is more sensitive and specific than Warthin-Starry staining. ${ }^{13}$ It is important to be aware that organisms may be difficult to identify in tissue sections, and negative special stains and immunoperoxidase do not exclude infection. Serology remains the gold standard for diagnosis of syphilis.

The sites most commonly affected by granulomatous inflammation are the lungs, skin and kidneys. ${ }^{14}$ Extensive review of the literature revealed only one other reported case of necrotising granulomatous inflammation found in a specimen of the glans penis. ${ }^{15}$ In this instance, no systemic cause was identified but was thought to be of possible autoimmune aetiology after serological and microbiological testing yielded no significant results.

In this case, STIs were not immediately considered, given the clinical history was not concerning for sexual risk factors and the mass was not typically ulcerative as expected with syphilitic or herpetic lesions. ${ }^{2}{ }^{16}$ There were neither clinical features of syphilitic chancres nor syphilitic balanitis of Follmann, a manifestation of primary syphilis in which there is erosive balanitis without chancre. ${ }^{1718}$ However, this case highlights that syphilis is an important differential diagnosis to consider for penile lesions. 
Over the last decade, there has been a resurgence of reported cases of syphilis in Australia, with a $135 \%$ increase between 2013 and 2017 among both men (119\%) and women (309\%). The incidence of syphilis in the Aboriginal and Torres Strait Islander indigenous population was 6.6 times higher than in the non-indigenous population. ${ }^{19}$ Similar increases in incidence have been reported in the UK, with a 70\% increase between 2014 and 2018, and the USA, with a 73\% increase between 2013 and 2017. 2021

The histopathological findings of necrotising granulomas, although not specific, prompted a further pathway of investigation for this patient. While they were suggestive of an infectious aetiology, clinical correlation, and particularly correlation with serological results, was critical to definitive diagnosis of syphilis.

\section{Learning points}

- Suspicious penile lesions should be considered malignant until proven otherwise.

- Given the broad range of differential diagnoses for penile lesions, a multidisciplinary approach is important in reaching a diagnosis.

- This case exemplifies the resurgence of syphilis in developed countries and is a reminder that it should be considered as a differential diagnosis in penile lesions.

Acknowledgements The authors would like to thank Dr Christopher Carmody, Medical Director of Sexual Health Services, South Western Sydney Local Health District, for his involvement in the patient's clinical care and draft revision.

Contributors CP contributed to literature review, data collection, conception and drafting of the report. LW contributed to drafting and revision of the report. VL contributed to data collection and revision. PR contributed to conception and revision of the report.

Funding The authors have not declared a specific grant for this research from any funding agency in the public, commercial or not-for-profit sectors.

Competing interests None declared.

Patient consent for publication Obtained.

Provenance and peer review Not commissioned; externally peer reviewed.

Open access This is an open access article distributed in accordance with the Creative Commons Attribution Non Commercial (CC BY-NC 4.0) license, which permits others to distribute, remix, adapt, build upon this work non-commercially, and license their derivative works on different terms, provided the original work is properly cited and the use is non-commercial. See: http://creativecommons.org/ licenses/by-nc/4.0/.

\section{REFERENCES}

1 Inn FX, Imran F-H, Ali MF, et al. Penile augmentation with resultant foreign material granuloma and sequalae. Malays J Med Sci 2012;19:81-3.

2 Bunker C, Porter W. Rook's Textbook of Dermatology. Ninth Edition, 2019: 1-52.

3 Mukhopadhyay AK. Primary involvement of penile skin in lepromatous leprosy. Indian J Lepr 2005:77:317-21.

4 Venyo AK-G. Tuberculosis of the penis: a review of the literature. Scientifica 2015;2015:1-11.

5 Pandhi RK, Singh N, Ramam M. Secondary syphilis: a clinicopathologic study. Int J Dermatol 1995;34:240-3.

6 Chipollini J, De la Rosa AH, Azizi M, et al. Patient presentation, differential diagnosis, and management of penile lesions. Can Urol Assoc J 2019;13:S2-S8.

7 Christodoulidou M, Sahdev V, Houssein S, et al. Epidemiology of penile cancer. Curr Prob/ Cancer 2015;39:126-36.

8 Micali G, Innocenzi D, Nasca MR et al. Squamous cell carcinoma of the penis. J Am Acad Dermatol 1996;35:432-51.

9 Schellhammer PF, Jordan GH, Robey EL, et al. Premalignant lesions and nonsquamous malignancy of the penis and carcinoma of the scrotum. Urol Clin North Am 1992;19:131-42.

10 Kumar V, Abbas AK, Aster JC. Robbins basic pathology. Elsevier Saunders, 2013.

11 Shah KK, Pritt BS, Alexander MP. Histopathologic review of granulomatous inflammation. J Clin Tuberc Other Mycobact Dis 2017;7:1-12.

12 Papini M, Bettacchi A, Guiducci A. Nodular secondary syphilis. Br J Dermatol 1998:138:704-5.

13 Hoang MP, High WA, Molberg KH. Secondary syphilis: a histologic and immunohistochemical evaluation. J Cutan Pathol 2004;31:595-9.

14 Woodard BH, Rosenberg SI, Farnham R, et al. Incidence and nature of primary granulomatous inflammation in surgically removed material. Am J Surg Pathol 1982;6:119-30.

15 Christodoulidou M, Bunker CB, Trevisan G, et al. Necrotizing granulomatous inflammation of the glans penis. BMJ Case Rep 2016;2016. doi:10.1136/bcr-2016216913. [Epub ahead of print: 24 Aug 2016].

16 Shim TN, Minhas S, Muneer A, et al. Atypical presentation of genital herpes simplex (HSV-2) in two patients with chronic lymphocytic leukemia. Acta Derm Venereol 2014;94:246-7.

17 Abdennader S, Janier M, Morel P. Syphilitic balanitis of Follmann: three case reports Acta Derm Venereol 2011:91:191-2.

18 Platsidaki E, Tsimbos I, Vassis P, et al. Syphilitic balanitis of Follmann: two case reports Int J Dermatol 2019:58:e55-7.

19 Kirby Institute. HIV, viral hepatitis and sexually transmissible infections in Australia annual surveillance report 2018; 2018.

20 Public Health England. Sexually transmitted infections and screening for Chlamydia in England, 2018; 2019.

21 Centers for Disease Control and Prevention. Sexually transmitted disease surveillance 2017 U.S Department of Health and Human Services; 2018.

Copyright 2021 BMJ Publishing Group. All rights reserved. For permission to reuse any of this content visit

https://www.bmi.com/company/products-services/rights-and-licensing/permissions/

BMJ Case Report Fellows may re-use this article for personal use and teaching without any further permission.

Become a Fellow of BMJ Case Reports today and you can:

- Submit as many cases as you like

- Enjoy fast sympathetic peer review and rapid publication of accepted articles

- Access all the published articles

Re-use any of the published material for personal use and teaching without further permission

Customer Service

If you have any further queries about your subscription, please contact our customer services team on +44 (0) 2071111105 or via email at support@bmj.com.

Visit casereports.bmj.com for more articles like this and to become a Fellow 